Crustal and Upper Mantle Velocity Model along the DOBRE-4

Profile from North Dobruja to the Central Region of the

Ukrainian Shield : 2. Geotectonic Interpretation

Starostenko, V.I.

2017

pÿStarostenko, V I, Janik, T, Gintov, O B , Lysynchuk, D V , Zroda , P , Czuba , W , Kolomiyets , E V , Aleksandrowski , P , Omelchenko , V D , Komminaho , K, Guterch , A , Tiira , T , Gryn , D N , Legostaeva , O V , Thybo , G \& Tolkunov , A V 2017 , ' Crustal and Upper Mantle Velocity Model along the DOBRE-4 Profile from North Dobruja to the Central Region of the Ukrainian Shield : 2. Geotectonic Interpretation ' , Izvestiya, Russian Academy pÿof Sciences. Physics of the Solid Earth , vol. 53 , no. 2 , pp. 205213 . https://doi.org/10.1134/S106935131702013

http://hdl.handle.net/10138/312485

https://doi.org/10.1134/S1069351317020136

publishedVersion

Downloaded from Helda, University of Helsinki institutional repository.

This is an electronic reprint of the original article.

This reprint may differ from the original in pagination and typographic detail.

Please cite the original version. 


\title{
Crustal and Upper Mantle Velocity Model along the DOBRE-4 Profile from North Dobruja to the Central Region of the Ukrainian Shield: 2 . Geotectonic Interpretation
}

V. I. Starostenko ${ }^{a}$ * , T. Janik ${ }^{b}$ ** , O. B. Gintov ${ }^{a}$, D. V. Lysynchuk ${ }^{a}$, P. Środa ${ }^{b}$, W. Czuba ${ }^{b}$, E. V. Kolomiyets ${ }^{a}$, P. Aleksandrowskic, $* * *$, V. D. Omelchenko ${ }^{a}$, K. Komminaho ${ }^{d, * * * *}$, A. Guterch ${ }^{b}$, T. Tiira ${ }^{d, * * * *}$, D. N. Gryn ${ }^{a}$, O. V. Legostaeva ${ }^{a}$, H. Thybo ${ }^{e * * * * *}$, and A. V. Tolkunov $f * * * * * *$

${ }^{a}$ Institute of Geophysics, National Academy of Sciences of Ukraine, Kiev, Ukraine

${ }^{b}$ Institute of Geophysics, Polish Academy of Sciences, Warsaw, Poland

${ }^{c}$ Polish Geological Institute-National Research Institute, Wroclaw, Poland

${ }^{d}$ Institute of Seismology, University of Helsinki, Helsinki, Finland

${ }^{e}$ Department of Geography and Geology, University of Copenhagen, Copenhagen, Denmark

${ }^{f}$ State Geophysical Enterprise Ukrgeofizika, Kiev, Ukraine

*e-mail: vstar@igph.kiev.ua

**e-mail:janik@igf.edu.pl

***e-mail:pale@pgi.gov.pl

****e-mail:Timo.Tiira@helsinki.fi

*****e-mail:THYBO@geol.ku.dk

******e-mail: geolog@ukrgeofizika.kiev.ua

Received February 24, 2016

\begin{abstract}
This part of the paper addresses the geotectonic interpretation of the velocity model obtained from the results of seismic studies under the DOBRE-4 project in Ukraine. The velocity field does not show distinct lateral changes from the Precambrian platform towards the younger tectonic structures in the southwest. Hence, based on the seismic data alone, it is not possible to recognize the tectonic units that are known on the surface. The Moho has an undulating pattern over an interval with a length of $\sim 150 \mathrm{~km}$. The amplitude of the undulations reaches 8 to $17 \mathrm{~km}$. The similar wavelike behavior, although on a shorter spatial scale and lower amplitude, is also typical of the upper crust and upper mantle. The presence of several separate horizons in the folded crust revealed by the velocity model is consistent with the presence of the folded systems which have different extensions on the different depth levels in the Earth's crust. This situation is believed to be typical of folding on the lithospheric scale and to reflect the rheological stratification of the crust. The DOBRE-4 velocity section of the crust and adjacent part of the mantle promotes a clearer view of the geodynamical model describing the formation of the southwestern part of East European Platform in the Early Precambrian from the plate's tectonic standpoint.
\end{abstract}

DOI: $10.1134 / \mathrm{S} 1069351317020136$

\section{INTRODUCTION}

This work is devoted to the geotectonic interpretation of the results of wide-angle seismic observations under the DOBRE-4 project, which were considered in the first part of this paper (this issue, (Starostenko et al., 2017a)). The structure of the lithosphere of the East European Platform (EEP), together with the adjacent Paleozoic platform and Meso-Cenozoic Carpathian-Pannonian orogenic system in Central Europe, has been systematically studied over decades by the method of deep seismic sounding (DSS) (Sollogub, 1986; Litosfera ..., 1988; Chekunov et al., 1992; Grad et al., 2006b; Guterch et al., 2008; Bogdanova, 1996). The aim of the present study was to obtain a picture of the general structure of the Earth's crust and upper mantle in the southwestern part of the EEP, including its transition to the Trans-European Suture Zone (TESZ) (Fig. 1).

Previously (Starostenko et al., 2013), in the analysis of the physico-geological nature of the velocity boundaries obtained in the DOBRE-4 experiment, the interpretation was based on the key hypotheses of the biharmonic uncoupled folding (Cloetingh et al., 1999) which relies on the linear folding model (Biot 


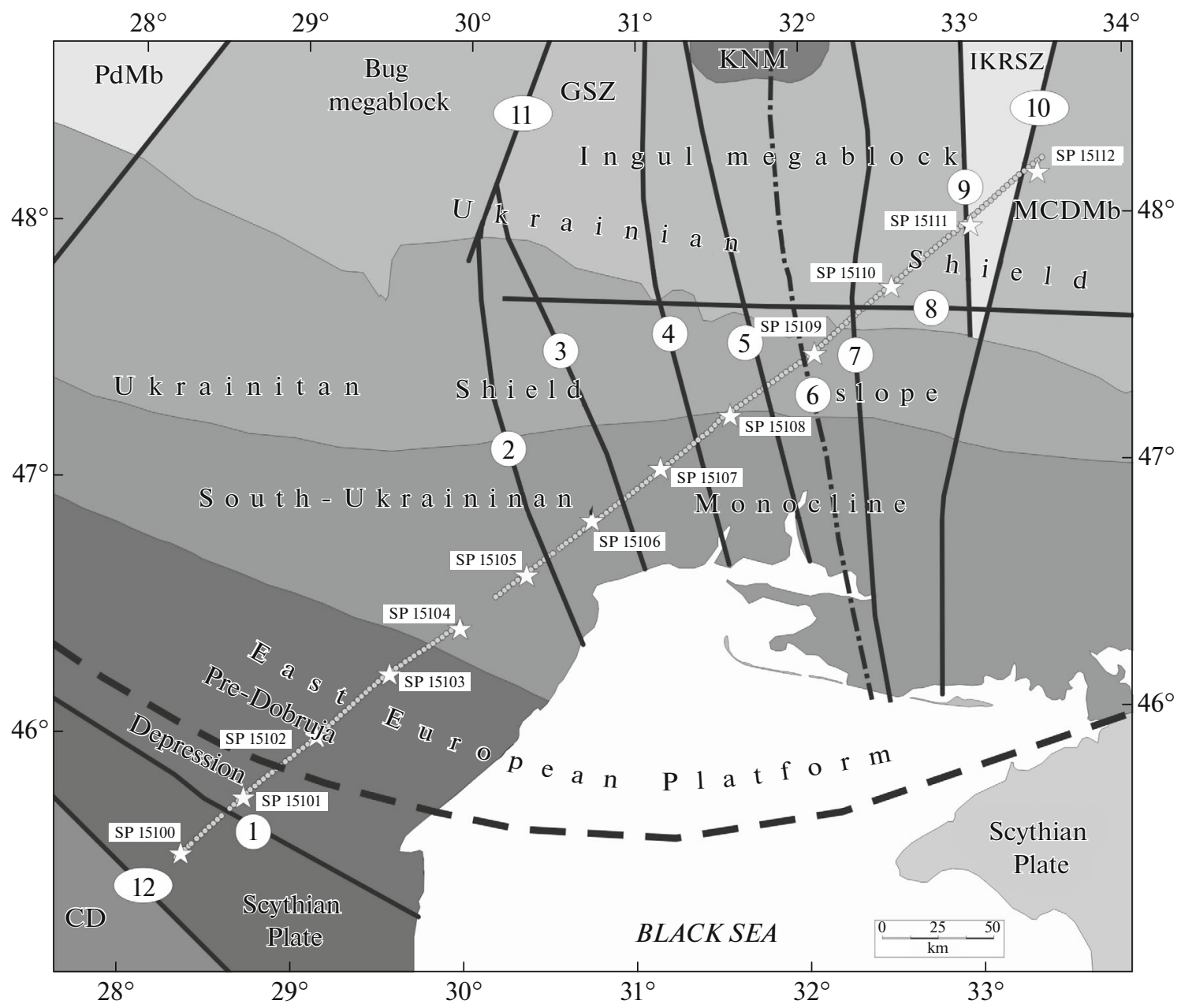

Fig. 1. The tectonic scheme for the region of study on the DOBRE-4 profile. PdMb is the Podol'sk megablock; MCDMb is the Middle Cis-Dnieper Megablockl; CD is Central Dobruja; GSZ is the Golovanevskaya suture zone, IKRSZ is the InguletsKrivoi Rog suture zone. Fault zones: 1, Kagul-Izmail; 2, Odessa; 3, Gvozdavskaya; 4, Pervomaiskaya; 5, Zvenigorodsko-Bratskaya; 6, the Kherson-Smolensk transregional tectonic suture (KhSTRTS); 7, Kirovogradskaya; 8, Konkskaya; 9, West Ingulets; 10, Krivoi Rog-Kremenchug; 11, Tal'novskaya; 12, Pechenega-Kamena.

et al., 1961) for the constant wavelength regular undulations and the empirical data (Sokoutis et al., 2005). Using this model and the data (Burov et al., 1993; Cloetingh et al., 2011), we described (Starostenko et al., 2013) the Moho undulations with a wavelength of $125-150 \mathrm{~km}$ together with the folds of the upper crust having a significantly shorter spatial period, which were revealed along the profile. The Moho topography was accounted for by the hypothetical folding of the cold lithosphere with a relatively strong mantle. The known geodynamical scenario of the Mesozoic evolution of the Black Sea region (Stampfli and Borel, 2002; Golonka, 2004; Kalvoda and Babek, 2010; Seghedi, 2001; 2012; Hippolyte, 2002) considered by us was also used for substantiating the idea of the significant crustal and mantle compression with the SW-NE axis, presumably related to the Cimmerian folding in the Dobruja region, which could have also promoted the formation of the lithospheric-scale folds in the studied territory.

In the present work, we also use another approach to analyzing the geological nature of the velocity section along the DOBRE-4 profile. This approach is more intimately related to the plate's tectonic model of the evolution of the lithosphere, particularly concerning the Ukrainian Shield (USh) which, together with the slope and a part of the South Ukrainian Monocline (SUM), occupies more than half of the profile. The approach suggested below relies on both the data of the DOBRE-4 experiment and on the results of the DSS on geotraverses IV and VIII (Sollogub, 1986a; 1986b), as well as on the other geological and geophysical data of the Ukrainian experts for the studied region (Il'chenko, 1987; Chekunov et al., 1989). 


\section{GEOLOGICAL INTERPRETATION OF THE MODEL}

The most remarkable peculiarity of the velocity section of the DOBRE-4 profile is the fact that this model contains three strikingly consistent syncline and anticline bends of the Moho with a wavelength of about $125-150 \mathrm{~km}$ and amplitude ranging from 8 to $17 \mathrm{~km}$ (Fig. 4 in Starostenko et al., 2017a). Hence, the crustal thickness strongly varies along the profile from 33-38 km in the interval between the shot points (SPs) 15104 and 15111 to 44-49 km between SPs 15108 and 15109 and in the region of SP 15106. Besides undulations in the Moho topography, a similar wavelike behavior, although on a smaller scale, is also characteristic of the velocity boundaries in the model of the upper crust and upper mantle.

\subsection{Sedimentary Cover}

The seismic data obtained on the DOBRE-4 profile allow us to somewhat refine, at places, the structure of the sedimentary cover and the pattern of the main tectonic boundaries traced in the near-surface horizons.

Judging by the behavior of the surface of the Riphean-Lower Paleozoic basement beneath the Lower Prut Horst of Northern Dobruja (LPHND) $\left(V_{\mathrm{p}} \approx\right.$ $5.8 \mathrm{~km} / \mathrm{s})$, the boundary between the horst and the Pre-Dobrujian Depression (PDD) (which is placed by the geological data at the base of the Neogene-Quaternary cover in the area of SP $15100+30 \mathrm{~km}$ ) manifests itself on the basement by the flexure-like bend with an amplitude as small as 100-200 $\mathrm{m}$. At the same time, the basement itself at a depth of $5.5 \mathrm{~km}$ continues to SP $15101+20 \mathrm{~km}$, sharply deepening northeast from SP 15101 at an angle of $\sim 9^{\circ}$. In principle, this may testify to the different behavior of the sedimentary-volcanic Upper Paleozoic cover $\left(V_{\mathrm{p}} \approx 2.7-3.82 \mathrm{~km} / \mathrm{s}\right)$ and Riphean-Lower Paleozoic basement at the boundary of the Northern Dobruja and EEP: the first is thrust over the PDD cover and the front of thrusting is noted in the region of SP $15100+30 \mathrm{~km}$, whereas the sharp boundary between the basements of Dobruja and the EEP (the transition from 5.8 to $\geq 6.0 \mathrm{~km} / \mathrm{s}$ ) lies at a depth of $5 \mathrm{~km}$ along the marginal suture of the EEP in the region of SP $15101+30 \mathrm{~km}$.

The DOBRE-4 velocity section of the sedimentary cover provides good data about the depth distribution of geological complexes of different age, although it does not always reflect, due to the intrinsic peculiarities of the technique, their structural-facial distinctions which play the key role in the tectonic zoning of the cover.

For instance, the layers with $V_{\mathrm{p}} \approx 4.70-2.60 \mathrm{~km} / \mathrm{s}$, corresponding to the Paleozoic-Mesozoic (Ordovician-Jurassic) terrigenous-clay and carbonate PDD formations, stretch throughout the entire SUM in the velocity section and do not trace its boundary with the
PDD. However, the topography of the layers monoclinally subsiding southwest and their thickness are fairly distinct: the thickness varies from a few hundred meters in the northeast to $3000 \mathrm{~m}$ near the marginal suture.

The Baikalian basement of the $\operatorname{PDD}\left(V_{\mathrm{p}} \approx 5.15 \mathrm{~km} / \mathrm{s}\right)$, composed of a granitized terrigenous formation with a thickness of $\sim 2000 \mathrm{~m}$, according to the seismic data, has a very complicated, keyboard structure with the amplitude of the vertical displacement between the neighboring blocks reaching $1 \mathrm{~km}$. This distinguishes it from the other sedimentary boundaries and suggests the northeastern boundary of the depression is in the region of SP $15104+10 \mathrm{~km}$, i.e., along River Gurunchuk.

Farther northeast, this layer has a velocity of $V_{\mathrm{p}} \approx$ $5.10 \mathrm{~km} / \mathrm{s}$ and corresponds to the Caledonian basement of the Moldavian Plate (Tectonic ..., 2007)-the Vendian-Lower Devonian complex of the carbonateterrigenous and terrigenous-clay formations with a thickness of up to $1 \mathrm{~km}$.

The area of the Ingul megablock between SP 1510915111 with velocity $V_{\mathrm{p}} \approx 5.45 \mathrm{~km} / \mathrm{s}$, which stretches from the surface to a depth of $\sim 1.5 \mathrm{~km}$ in the vicinity of SP 15110 is fairly interesting. This is the region of the outcropped granitoids of the Kirovograd and Dnepropetrovsk complexes, as well as the IngulIngulets gneisses; therefore, the $V_{\mathrm{p}}$ velocities here should not be lower than 5.8-6.0 km/s. However, the Ingul megablock is part of the USh, which is most fractured by the faults. The width of the Kirovograd, West Ingulets, and other fault zones reaches $10-20 \mathrm{~km}$. Therefore, the segment of the Earth's crust with velocity $V_{\mathrm{p}} \approx 5.45 \mathrm{~km} / \mathrm{s}$ is most likely to be associated with the decompaction of the crystalline rocks in the fault zones.

\subsection{Crystalline Crust, the Moho, and Upper Mantle}

The subhorizontal crustal compression is revealed in the Neo-Archaean and the first half of Early Proterozoic (from $\geq 2.6$ to $2.1 \mathrm{Ga}$ ) from the tectonophysical data (Gintov and Mychak, 2011b). The horizontal reflectors at a depth from 10 to $30 \mathrm{~km}$ (Sollogub and Il'chenko, 1986b) correspond to the detachment surfaces which emerged as a result of the differential displacements of separate crustal horizons in the Archaean and Proterozoic (see Discussion).

It cannot be asserted that during such a long time period the crust only experienced compression. During the time interval of 2.6-2.1 Ga, the sedimentary basin of the Ingul-Ingulets rock series had been formed, which testifies to the presence of the extension phase as well. However, the compression phases are always better reconstructed from the tectonophysical data than the extension phases because the compression deformations are more manifest. 
In addition to the overall deepening of the PreJurassic and Precambrian EEP basement towards Dobruja, the detailed crustal velocity section up to a depth of $7 \mathrm{~km}$ along the DOBRE-4 profile also reflects two other important features. Between the shot points SP 15101 and SP 15102 there is an abrupt $\mathrm{V}$-shaped trough in the velocity horizons ranging from 2.30 to $5.80 \mathrm{~km} / \mathrm{s}$, which clearly marks the marginal fault zone of the EEP and more accurately delineates the boundary of the latter. The similar steep subsidence of the velocity horizons ranging from 5.43 to $6.14 \mathrm{~km} / \mathrm{s}$ is observed between SP $15108+30 \mathrm{~km}$ and SP 15110. It maps onto the axial zone of the KhersonSmolensk Transregional tectonic suture (KhSTRTS). Overall, the entire crustal block between the Zvenigorod-Bratsk and Kirovograd fault zones down to a depth of $15 \mathrm{~km}$ is distinguished in the profile by relatively low velocities (by 0.05 to $0.10 \mathrm{~km} / \mathrm{s}$ lower than the neighboring areas), which may testify to the dilatant decompaction of the crust in the fault zones.

The velocity section of the lower part of the crust and adjacent mantle also gives new interesting results.

(1) On the DOBRE-4 profile, a distinct Moho depression is identified between SP 15108 and SP 15109 (the crustal thickness reaches $45 \mathrm{~km}$ ), which should be related to KhSTRTS. This depression has a different nature than the known Moho depressions between SP 15105 and SP 15106 (the crustal thickness on the profile is $47 \mathrm{~km}$ ) and the depression observed northeast of SP 15111. The last Moho depression (crustal thickness up to $53 \mathrm{~km}$ ) is established on geotraverses VIII and V in the interval that had not been captured by the DOBRE-4 profile. Both Moho depressions were previously considered by V.B. Sollogub (Sollogub, 1986) as the "mountain roots" associated with the Early Proterozoic Golovanevsksys and InguletsKrivoi Rog "protogeosynclines." Subsequently, they were named the suture zones, which does not contradict the plate tectonic mechanism of their formation.

Qualifying the Golovanevskaya suture zone (GSZ) and Ingulets-Krivoi Rog suture zone (IKRSZ) as the protogeosynclines or suture zones was explained by the extensive presence of the classical geosynclinal formations in them: the association of the deep-water siliceous-clayey, ferruginous-siliceous, and carbonate sediments with the basic and ultrabasic lava products. Both zones have been finally formed under the transpression conditions which determined the specific features of their structure noted before.

For the KhSTRTS zone, these rock associations are untypical; besides, this zone was formed in the conditions of transtension. Therefore, the Moho depression in this region is likely to have a different origin. The ubiquitous presence of magmatogene and anatectic granites in the KhSTRTS zone testifies to the strong differentiation and stratification of the upper lithosphere, more contrasting separation of the crust and mantle without the formation of the crustal- mantle mixture. In the DOBRE-4, it can be seen that between SP 15108 and SP 15109, the Moho clearly separates the crustal layer with the velocity of $6.70 \mathrm{~km} / \mathrm{s}$ from the mantle where the velocity is $8.40 \mathrm{~km} / \mathrm{s}$.

The mantle area with a velocity of $8.35-8.40 \mathrm{~km} / \mathrm{s}$, which is the crustal base in the KhSTRTS zone, farther southwest deepens by almost $20 \mathrm{~km}$ to a depth of $63 \mathrm{~km}$. The reflecting boundary which limits it from above subdivides the lithospheric mantle into two layers: the upper layer with mean velocity $8.20 \mathrm{~km} / \mathrm{s}$ and the lower layer with mean velocity $8.39 \mathrm{~km} / \mathrm{s}$. This sharp splitting of the mantle is associated with the geodynamical processes (see Discussion). In respect of this, we note that in the opinion of N.I. Pavlenkova and G.A. Pavlenkova (N. Pavlenkova and G. Pavlenkova, 2014, p. 110), velocities of $8.4 \mathrm{~km} / \mathrm{s}$ in the top portions of the mantle are hard to explain because among the mantle rocks no samples with such characteristics have been found.

(2) A direct correlation of the GSZ and IKRSZ, which were identified by the geological and geophysical methods with the intervals of crustal thickening, despite their imperfect (incomplete) coincidence in the plane which will be discussed below, is undoubted. Firstly, they have common fault zones: the Tal'novskaya and Vradievskaya fault zones in the western part of the GSZ and the Krivoi Rog-Kremenchug fault zone in the eastern part of IKRSZ. Secondly, they share the strike of the suture zones and Moho depressions. Moreover, even the variations in the strikes are identical: for example, the bend in the GSZ at a latitude of $48^{\circ}$ is accompanied by a similar bend in the Moho depression. Thirdly, one should take into account that the GSZ and IKRSZ were formed under the conditions of transpression, which can be considered as a combination of the deformations of a simple and pure shear with the subhorizontal position of the plane $\sigma_{1} \sigma_{3}$. In these conditions, the lengthening of the crustal prisms composing both suture zones should have occurred both submeridionally and vertically.

The structural-tectonophysical studies within the GSZ and IKRSZ (Gintov and Isai, 1988; Gintov et al., 1990; 2011c; Starostenko et al., 2013a) also suggest the presence of both the horizontal and vertical components in the displacement of the rock masses. The lateral displacement of the material along the shear zones is reflected in the horizontal plane by the elongation of micas, lenses of quartz grains, feldspar recrystallized into the lenses of quartz grains, cordierite, etc. Vertical displacement manifests itself by the elongation of micas, quartz tables, and feldspar along the dip. Several stages (Pervomaiskii, Krivorozhskii) and phases of the deformation (Tal'novskaya, etc.) are identified as normal faults with a strike-slip component.

These data suggest that the formation of the Moho depressions beneath the GSZ and IKRSZ is associated with the crustal thickening beneath them due to the downward displacement of the crustal material. 
(3) Both Moho depressions are shifted relative to the suture zones traced on the surface: beneath the GSZ, by $\sim 40 \mathrm{~km}$ in the west azimuths, and beneath the IKRSZ by $\sim 40 \mathrm{~km}$ in the east azimuths. In (Gintov and Mychak, 2011b) it was shown that at the end of the Early Proterozoic the upper part of the Ingul megablock has diverged by at least $70 \mathrm{~km}$. Hence, if we combine these two processes, we obtain that during the interval 2.1-1.75 Ga ago, both suture zones diverged near the surface (in this case, the erosional downcut can be disregarded) by $70 \mathrm{~km}$; at the Moho depth, the divergence was $150 \mathrm{~km}$.

This difference in the amount of the extension of the upper part of the lithosphere of the Ingul megablock at two levels which differ in depth by as little as $40-50 \mathrm{~km}$ indicates the different rheology of the upper and lower crust in the Precambrian. This question is discussed below.

\section{DISCUSSION}

The considered mechanism of formation of the GSZ and IKRSZ is consistent with the idea of the kinematics of the crustal-penetrating transpressive shear zones described in (Chardon et al., 2009). The authors of the cited paper, based on the data about the increased temperatures $\left(900-1100^{\circ} \mathrm{C}\right.$ and higher) on the Moho in the Precambrian ultrahot accretionary orogens (UHOs) and the overall weakening of the lithosphere and lower crust, arrive at the conclusion that the development of the subvertical linear-schistous texture of the rocks is associated, under compression, with the motion of the material along the shear zonethe flow combining the lateral advection and the predominant downward component.

In this work it is also noted that due to the extremely thin lithosphere and high Moho temperature, within the UHO crust, there are two layers: the upper, stiff layer and the thicker flowable lower layer, which are mediated by the transitional layer. The subMoho lithospheric mantle has even lower viscosity approaching that of the asthenosphere.

Due to this stratification, the upper crust responds to the tectonic stresses as a rigid (almost rigid) body, whereas the lower crust responds as a viscoplastic body: in addition to the mentioned two-dimensional deformation in the relatively narrow shear zones, a subhorizontal flow of the rock material appears on the separate intervals within these zones and between them. This subhorizontal flow is fixed by the subhorizontal seismic boundaries and sites. The transitional layer is most likely to manifest itself by the reflecting boundary at a depth of $13-22 \mathrm{~km}$, which separates the crustal layer with the velocity of $6.35 \mathrm{~km} / \mathrm{s}$ from the layer with the velocity $6.53 \mathrm{~km} / \mathrm{s}$ and is tracked along the entire DOBRE-4 profile.

Clearly, the horizontal lengthening of the lithosphere in the lower crust and mantle is larger than the width of the gap in the upper crust, which is just responsible for the shift of the Moho depressions relative to the boundaries of the suture zones on the surface.

The rheological peculiarity of the lower crust consists in the fact that it repeats the fault zones and other deformational structures observed in the upper crust, although the horizontal flow of the material should naturally change their positions and orientation.

The question of qualifying (or not qualifying) the Ingul megablock at the end of the Archaean and in the Early Proterozoic as a UHO is the responsibility of petrologists. However, the geophysical data show that many features of a UHO are characteristic of the megablock.

The following question is another equally important point. The compression of the lithosphere supported by the CDP data, which occurred in the Archaean and Early Proterozoic as a result of the oblique convergence of the Western and Eastern microplates not only implies the transpressional deformation of their active margins with the formation of GSZ and IKRSZ but also the subduction-obduction of the oceanic or suboceanic lithosphere that separated these microplates.

Since clear geophysical evidence of the Precambrian subduction or obduction of the oceanic lithosphere, in its classical form, has not been observed, we suggest considering the results of the $2 \mathrm{D}$ thermomechanical-petrologic modeling (Sizova et al., 2010). This modeling has shown that during the period between the Archaean and the end of Early Proterozoic, the plate tectonic processes in the tectonosphere of the Earth could have developed by three scenarios: nonsubduction, presubduction, and classical subduction, depending on the Moho temperature.

The first scenario (the Moho temperature is by $200^{\circ}-250^{\circ}$ higher than at present), the melt flows rising from the sublithospheric mantle split the oceanic plate into small fragments which move guided by the intraplate stresses and do not subduct, although small underthrusts beneath the continental lithosphere (with an amplitude of up to $50 \mathrm{~km}$ ) may occur.

In the second scenario (the Moho temperature is by $175^{\circ}-200^{\circ}$ higher than at present), the plates are weakened by the intense uplifting of the melts from the sublithospheric mantle. Under the convergence, instead of the independent unilateral subduction, small-scale underthrusting of the oceanic plate beneath the continental one with a horizontal offsets up to $100 \mathrm{~km}$ takes place.

The classical variant of the Precambrian subduction, when the oceanic plate subducts into the asthenosphere beneath the continental plate, is only observed at a Moho temperature $0^{\circ}-175^{\circ}$ higher than at present.

For the case considered in the present work, the second scenario-presubduction or flat subduction, when the oceanic plate does not sink into the mantle 
(a)

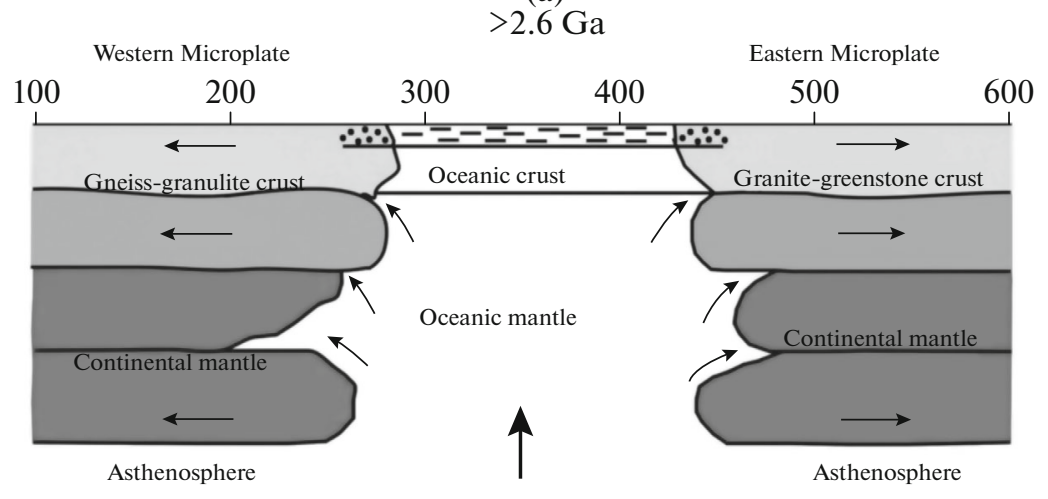

(b)

$>2.3-2.4 \mathrm{Ga}$

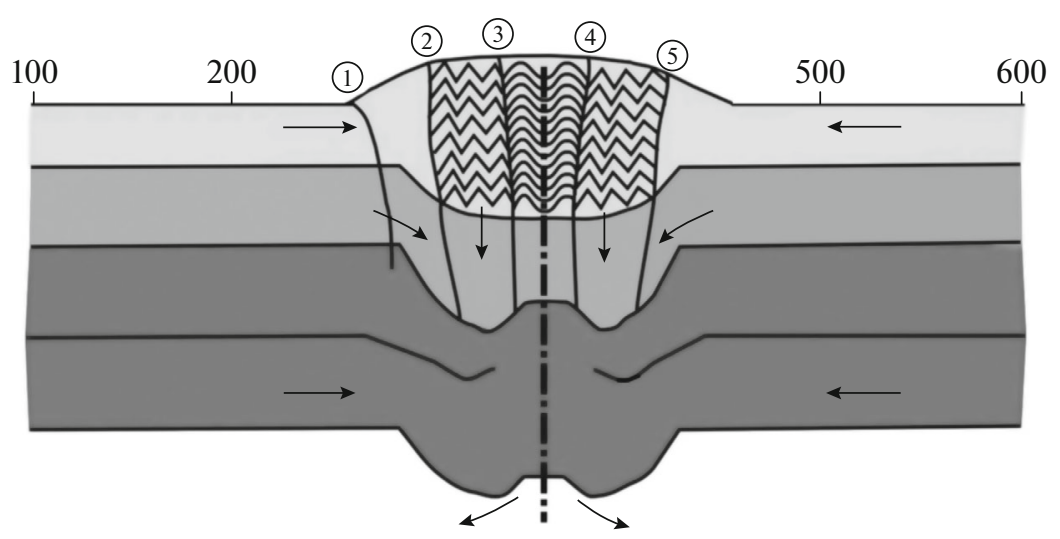

(c)
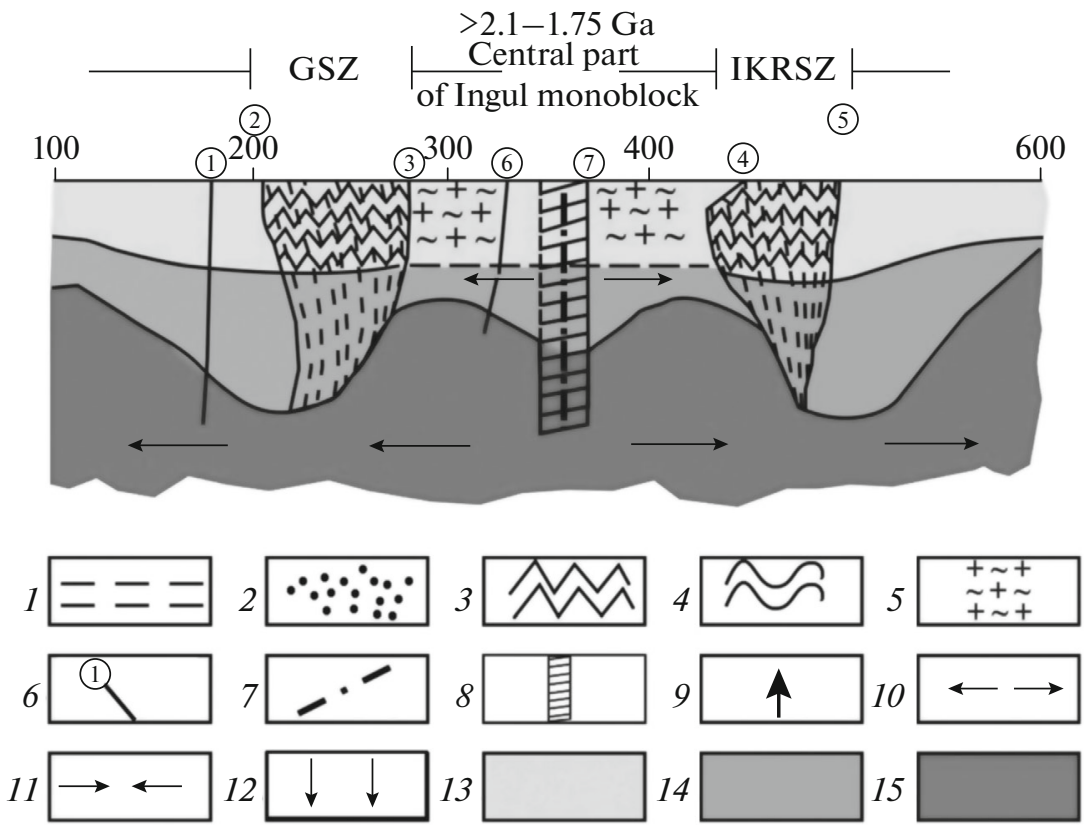

Fig. 2. The simplified scheme of the geodynamical evolution for the Central part of USh in the Neo-Archaean-Early Proterozoic: 1, oceanic basin; 2, the deposits of the Bug (west) and Krivoi Rog (west) series; 3, the folding in the rocks of the Bug and Krivoi Rog series; 4, the folding in the rocks of the Ingul-Ingulets series; 5, granitized rocks of the Ingul-Ingulets series, granitoids of the Kirovograd, Novoukrainskii, and Korsun'-Novomirgorodskii complexes; 6, the axial lines of the fault zones (numbers in the circles): 1, Odessa; 2, Tal'novskaya; 3, Pervomaiskaya; 4, West Ingulets; 5, Krivoi Rog-Kremenchug; 6, ZvenigorodskoBratskaya; 7, Kirovograd; 7, the axial line of the Kherson-Smolensk transregional divergence zone; 8 , the minimal width of the zone; 9 , the direction of uplifting of the Neo-Archaean plume; 10, the direction of divergence of the microplates; 11, the direction of the convergence of the microplate; 12 , UHO lengthening in the vertical direction; 13, upper crust; 14, lower crust; 15, mantle. 
but very gently thrusts under the continental plate-is most suitable. Here, it should be noted that since the lithospheric mantle has low viscosity, as was shown above, the underthrusting takes place at many depth levels.

One of them is perhaps captured by the described reflecting boundary which originate beneath the KhSTRTS zone and is tracked $250 \mathrm{~km}$ southwestwards where it deepens to a depth of $63 \mathrm{~km}$. The mentioned transitional layer at the depths of $13-22 \mathrm{~km}$ is also likely to reflect the response of the rheologically stratified Precambrian crust to the flat subduction and its different extension at the different depth levels.

The described data are schematically illustrated in Figs. 2a-2c.

Figure 2a shows the hypothetical Neo-Archaean divergent stage of the Ingul megablock evolution, the divergence of the Western and Eastern microplates, and the beginning of sedimentation of the Bug (in the west) and Krivoi Rog (in the east) series of volcanicsedimentary deposits in the passive margins of these microplates. The crust in the figure is represented by two rheologically different horizons, the upper rigid and the lower plastic ones. The inflow of the asthenospheric plume from below was accompanied by the squeezing of the oceanic lithosphere sideways, leading to its intrusion between the lithosheets and to the divergence of microplates (nonsubduction scenario). This stage is not captured by the tectonophysical data but is assumed by the presence of the Bug and Krivoi Rog series with the lower age of 2.8 Ga (Geohronologiya ..., 2008). The figure also shows that under the collision, the oceanic mantle that has previously intruded into the marginal subcrustal space can form the body of the crustal-mantle mixture (Fig. 2b).

The Archaean turning to the Proterozoic (2.6-2.5 Ga) was marked by the commencement of the convergent stage in the evolution of the lithosphere of the Ingul megablock (not shown), which is recorded in the tectonophysical data by the formation of the right-lateral (under compression) Pervomaiskaya, West-Ingulets, and a number of smaller scale fault zones, as well as by the beginning of folding in the rocks of the Bug and Krivoi Rog series. This stage was accompanied by the flat subduction of the oceanic lithosphere beneath the Western and Eastern microplates.

Figure $2 \mathrm{~b}$ illustrates the collision stage of the Western and Eastern microplates 2.3-2.4 Ga ago (the divergence stage associated with the accumulation of the Ingul-Ingulets series is omitted), when they were only separated by the collisional suture with the width unfortunately unknown. At this stage, the Tal'novskaya and Krivoi Rog fault zones had been formed; and the development of the GSZ and IKRSZ, which subsequently detached from the Western and Eastern microplates, had been finalized. The Moho depression separated by the collisional suture was formed beneath the suture zones. The vertical arrows pointing downwards indicate the described descending motion of the rock material under the side compression.

Figure 2c illustrates the recent structure of the lithosphere (without the Riphean and younger deposits) beneath the DOBRE-4 profile. This structure has an age of $2.1-1.75 \mathrm{Ga}$. The crustal divergence in the interval between 2.1 and $1.75 \mathrm{Ga}$ is recorded in the tectonophysical data (Gintov and Mychak, 2011a). The GSZ and IKRSZ had got separated by $200 \mathrm{~km}$ along the profile, whereas the Moho depressions between them diverged by $280 \mathrm{~km}$. Here, the axial zone of the divergence is not filled by the oceanic crust (the fact that the initial stage of the formation of the oceanic crust is still in progress is perhaps demonstrated by the anomalous abundance (for the USh) of basic and ultrabasic dike rocks in the Ingul megablock (Bogdanova et al., 2013). Instead, the axial zone of the divergence is filled by granite plutons formed by palingenesis and the remelting of the Proterozoic crust. The difference in the amount of divergence indicated here and in Section 6.2 (the width of the suture zones should also be taken into account) is likely to be associated with the width of the collisional suture which is unknown (Fig. 2b).

\section{CONCLUSIONS}

A large-scale wide-angle experiment on studying the deep structure of the Earth's crust and upper mantle has been conducted in the southeastern part of Ukraine. The high quality of the obtained seismic data made it possible to document the structures of the LPHND, PDD, SUM, and the southern slope of USh and its outcropped part.

The boundary between the PDD and SUM has been recognized due to the complicated keyboard structure of the PDD basement where the amplitude of the vertical displacements of the neighboring blocks reaches $1 \mathrm{~km}$.

The velocity section demonstrates the overall subsidence of the Pre-Jurassic and Precambrian EEP basements towards Dobruja with two important peculiarities: (1) a sharp V-shaped trough with $P$-wave velocities ranging within 2.30 and $5.80 \mathrm{~km} / \mathrm{s}$ between SP 15101 and SP 15102, which corresponds to the ancient fault zone of the EEP and allows us to refine its boundary; and (2) a very similar sharp deepening between SP $15108+30 \mathrm{~km}$ and SP 15110 with the seismic velocities varying from 5.43 to $6.14 \mathrm{~km} / \mathrm{s}$, which corresponds to the axial zone of the Kherson-Smolensk interregional tectonic suture.

Two lithospheric-scale Moho depressions were revealed based on the seismic data. The first depression is identified between SP 15108 and SP 15109. The crustal thickness here reaches $45 \mathrm{~km}$. The crustal velocity $V_{\mathrm{p}} \approx 6.7 \mathrm{~km} / \mathrm{s}$ sharply changes in the Moho to $V_{\mathrm{p}} \approx 8.4 \mathrm{~km} / \mathrm{s}$ in the mantle. These works were the first to reveal this Moho depression associated with the 
Kherson-Smolensk suture zone. The depression has a different character than that shown on Geotraverse VIII and on the DOBRE-4 profile itself between SP 15105 and SP 15106, where the crustal thickness is 57 $\mathrm{km}$ and the mantle velocities are $\sim 8.2 \mathrm{~km} / \mathrm{s}$.

The mantle depression between SP 15105 and SP 15106 corresponds to the GSZ. A similar depression is revealed on geotraverses IV and VIII beneath the IKRSZ. As a result of the extension of the lithosphere, both these Moho depressions are shifted relative to the corresponding suture zones as tracked on the surface. The distance between the GSZ and IKRSZ is $70 \mathrm{~km}$ on the ground surface and $150 \mathrm{~km}$ at the Moho depth. This difference in the amount of the extension of the upper part of the lithosphere at two depth levels which differ by as little as $40-50 \mathrm{~km}$ suggests the different rheology of the upper and lower crust in the Precambrian. The transitional layer separating the upper and lower parts of the crust having different rheologies are fixed in the velocity section at a depth of $13-22 \mathrm{~km}$.

The DOBRE-4 velocity section of the crust and adjacent part of the mantle promotes a clearer idea of the geodynamical model describing the formation of the southwestern part of the East European Platform in the Early Precambrian from the standpoint of plate tectonics.

\section{REFERENCES}

Biot, M.A., Theory of folding of stratified viscoelastic media and its implications in tectonics and orogenesis, Geol. Soc. Am. Bull, 1961, vol. 72, pp. 1595-1620.

Bogdanova, S.V., Pashkevich, I.K., Gorbatschev, R., and Orlyuk, M.I., Riphean rifting and major Palaeoproterozoic crustal boundaries in the basement of the East European Craton: geology and geophysics, Tectonophysics, 1996, vol. 268, pp. 1-21.

Bogdanova, S.V., Ginto, O.B., Kurlovich, D.M., Lubnina, N.V., Nilsson, M.K., Orlyuk, M.I., Pashkevich, I.K., Shumlyanskyy, L.V., and Starostenko, V.I., Late Palaeoproterozoic mafic dyking in the Ukrainian Shield of Volgo-Sarmatia caused by rotation during the assembly of supercontinent Columbia (Nuna), Lithos, 2013, vol. 174, pp. 196-216.

Burov, E.B., Lobkovsky, L.I., Cloetingh, S., and Nikishin, A.M., Continental lithosphere folding in Central Asia, part II: Constraints from gravity and topography, Tectonophysics, 1993, vol. 226, pp. 73-87.

Chardon, D., Gapais, D., and Cagnard, F., Flow of ultrahot orogens: a view from the Precambrian, clues for the Phanerozoic, Tectonophysics, 2009, vol. 477, pp. 105-118.

Chekunov, A.V., et al., Litosfera Tsentral'noi $i$ Vostochnoi Evropy: metodika i rezul'taty kompleksnoi interpretatsii (Lithosphere of Central and East Europe: techniques and results of multiinstrumental interpretation), K.: Naukova dumka. 1992. $247 \mathrm{c}$.

Chekunov, A.V., Sollogub, V.B., Galetskii, L.S., and Kurlov, N.S., Geodynamic model for the central part of the
Ukrainian Shield and Krivoi Rog Superdeep Borehole, Geofiz. Zh., 1989, vol. 11, no. 4, pp. 3-13.

Cloetingh, S., Burov, E., and Poliakov, A., Lithosphere folding: primary response to compression? (from Central Asia to Paris Basin), Tectonics, 1999, vol. 18, pp. 10641083.

Cloetingh, S. and Burov, E., Lithospheric folding and sedimentary basin evolution: a review and analysis of formation mechanisms, Basin Res., 2011, vol. 23, pp. 257-290.

Geokhronologiya rannego dokembriya Ukrainskogo shchita.Proterozoi (Geochronology of Early Precambrian of the Ukrainian Shield. The Proterozoic), Shcherbak, N.P., Ed., Kiev: Naukova Dumka, 2008.

Gintov, O.B. and Isai, V.M., Tektonofizicheskie issledovaniya razlomov konsolidirovannoi kory (Tectonophysical Studies of the Faults in the Crystalline Crust), Kiev: Naukova dumka, 1988.

Gintov, O.B., Isai, V.M., and Kovalenko, V.N., Tectonophysical data on the formation mechanism of the first-order folds in the Krivoi Rog basin by the example of the Likhmanovskaya structure, Geol. Zh., 1990, no. 5, pp. 115-123.

Gintov, O.B. and Mychak, S.V., Geodynamic evolution of the Ingul megablock of the Ukrainian Shield according to the geological-geophysical and tectonophysical data I, Geofiz. Zh., 2011a, vol. 33, no. 3, pp. 102-118.

Gintov, O.B. and Mychak, S.V., Crustal stress states and strains in the central part of the Ingul megablock according to the results of tectonophysical study of the Novoukrainskii massif, Geofiz. Zh., 2011b, vol. 33, no. 2, pp. 28-45.

Golonka, J., Plate tectonic evolution of the southern margin of Eurasia in the Mesozoic and Cenozoic, Tectonophysics, 2004, vol. 381, pp. 235-273.

Grad, M., Jensen, S.L., Keller, G.R., Guterch, A., Thybo, H., Janik, T., Tiira, T., Yliniemi, J., Luosto, U., Motuza, G., Nasedkin, V., Czuba, W., Gaczynski, E., Środa, P., Miller, K.C., et al., Crustal structure of the Trans-European suture zone region along POLONAISE'97 seismic profile P4, J. Geophys. Res., 2003, vol. 108, p. 2541.

Grad, M., Janik, T., Guterch, A., Środa, P., Czuba, W., EUROBRIDGE'94-97, POLONAISE'97 and CELEBRATION 2000 Collab., Lithospheric structure of the western part of the East European Craton investigated by deep seismic profiles, Geol. Q., 2006b, vol. 50, no. 1, pp. 9-22.

Guterch, A., Grad, M., and Keller, G.R., Crust and lithospheric structure-long range controlled source seismic experiments in Europe, Treatise Geophys., Schubert, G., Romanowicz, B., and Dziewonski, A., Eds., Amsterdam: Elsevier, 2008, vol. 1, pp. 533-558.

Hippolyte, J.C., Geodynamics of Dobrogea (Romania): new constraints on the evolution of the TornquistTeisseyre line, the Black Sea and the Carpathians, Tectonophysics, 2002, vol. 357, pp. 33-53.

Il'chenko, T.V., Crustal velocity model of the Ukrainian Shield along Geortraverse VIII (Reni-Krivoi Rog), Geofiz. Zh., 1987, vol. 9, no. 1, pp. 44-51.

Kalvoda, J. and Bábek, O., The margins of Laurussia in Central and Southeast Europe and Southwest Asia, Gondwana Res., 2010, vol. 17, pp. 526-545.

Litosfera Tsentral'noi i Vostochnoi Evropy: geotraversy IV, VI, VIII (Lithosphere of Central and Eastern Europe: Geotra- 
verses IV, VI, VIII), Sollogub, V.B., Ed., Kiev: Naukova Dumka, 1988.

Pavlenkova, N.I. and Pavlenkova, G.A., Stroenie zemnoi kory i verkhnei mantii Severnoi Evrazii po dannym seismicheskogo profilirovaniya s yadernymi vzryvami (The Structure of the Earth's Crust and Upper Mantle of Northern Eurasia According to the Nuclear-Explosion Seismic Profiling Data), Moscow: GEOKART, 2014.

Seghedi, A., The North Dobrogea orogenic belt (Romania): a review, in Peri-Tethys Memoir 6: Peri-Tethyan Rift, Wrench Basins and Passive Margins, Ziegler, P.A., Cavazza, W., Robertson, A.F.H., Crasquin-Soleau, S., Eds., Memoires du Museum national d'Histoire naturelle, 2001, vol. 186, pp. 237-257.

Seghedi, A., Palaeozoic formations from Dobrogea and Pre-Dobrogea-an overview, Turkish J. Earth Sci., 2012, vol. 21, pp. 669-721.

Sizova, E., Gerya, T., Brown, M., and Perchuk, L., Subduction styles in the Precambrian: insight from numerical experiments, Lithos, 2010, vol. 116, no. 3, pp. 209-229.

Sokoutis, D., Burg, J.-P., Bonini, M., Corti, G., and Cloetingh, S., Lithospheric-scale structures from the perspective of analogue continental collision, Tectonophysics, 2005, vol. 406, pp. 1-15.

Sollogub, V.B., Litosfera Ukrainy (Lithosphere of Ukraine), Kiev: Nauk. Dumka, 1986.
Sollogub, V.B. and Il'chenko, T.V., Velocity model of Geotraverse VIII, Dokl. Akad. Nauk Ukr. SSR, Ser. B., 1986, no. 12 , pp. 14-16.

Stampfli, G.L. and Borel, G.D., A plate tectonic model for the Paleozoic and Mesozoic constrained by dynamic plate boundaries and restored synthetic oceanic isochrones, Earth Planet. Sci. Lett., 2002, vol. 196, pp. 17-33.

Starostenko, V., Janik, T., Lysynchuk, D., Środa, P., Czuba, W., Kolomiyets, K., Aleksandrowski, P., Gintov, O., Omelchenko, V., Komminaho, K., Guterch, A., Tiira, T., Gryn, D., Legostaeva, O., Thybo, H., and Tolkunov, A., Mesozoic (?) lithosphere-scale buckling of the East European Craton in Southern Ukraine: DOBRE-4 deep seismic profile, Geophys. J. Int., 2013, vol. 195, no. 2, pp. 740-766.

Starostenko, V.I., Yanik, T., Gintov, O.B., Lysynchuk, D.V., Środa, P., Czuba, V., Kolomiets, E.V., Aleksandrovskii, P., Omel'chenko, V.D., Kominaho, K., Guterkh, A., Tiira, T., Grin', D.N., Legostaeva, O.V., Thybo, G., and Tolkunov, A.V., Crustal and upper mantle velocity model along DOBRE-4 profile from North Dobruja to central region of Ukrainian Shield: 1. Seismic data, Izv., Phys. Solid Earth, 2017, no. 2 (in press).

Tektonicheskaya karta Ukrainy. Masshtab 1 : 1000000. Ch. I Poyasnitel'naya zapiska (1 : 1000000 Tectonic Map of Ukraine, Part 1, Explanatory Note), Gurskii, D.S. and Kruglov, S.S., Eds., Kiev: UkrDGRI, 2007.

Translated by M. Nazarenko 